\title{
On Foreign Direct Investment from the ASEAN-8 Countries: A Panel Data Estimation
}

\author{
INDRA SUHENDRA $^{1 *}$, NAVIK ISTIKOMAH ${ }^{2}$, CEP JANDI ANWAR $^{3}$
}

${ }^{1,3}$ Department of Economics and Development Studies, Faculty of Economics and Business, University of Sultan Ageng Tirtayasa, Banten, INDONESIA

${ }^{2}$ Department of Economics Education, Faculty of Economics and Business Education, Indonesia

University of Education, Bandung, INDONESIA

\begin{abstract}
This paper examines how capital flight, loan interest rates, inflation, exchange rates and economic growth influence foreign direct investment in the ASEAN-8 countries. We apply fixed effect estimation to panel data for data belonging to eight countries from the period 1994 to 2018. The results show that capital flight and economic growth have a positive and significant effect on foreign direct investment. An increase in capital flight, capital retain from sources of funds which greater than the use of funds, has encouraged foreign direct investment to increase. Furthermore, increased economic growth has stimulated foreign direct investment. We find that an increase in loan interest rate (SIBOR), inflation and depreciation of the exchange rate triggers a significant decline in foreign direct investment. This finding implies that capital retention from capital flight and economic growth are the main factors that create an increase in foreign direct investment in the ASEAN-8 countries. Meanwhile, loan interest rates (SIBOR), inflation and depreciation of the exchange rate are the risk factors that investors need to consider when investing in those particular countries. This paper is useful for policy makers in the ASEAN-8 countries to consider these five variables, as the important factors that significantly influence foreign direct investment in the ASEAN-8 countries.
\end{abstract}

Key-Words: Foreign Direct Investment; Loan Interest Rates; Inflation; Exchange Rate; Economic Growth; The ASEAN-8 Countries; Panel Data Model; Fixed Effect Estimation

Received: April 26, 2021. Revised: December 13, 2021. Accepted: January 9, 2022. Published: January 10, 2022.

\section{Introduction}

The scarcity of domestic capital as a source of development financing in developing countries has encouraged the use of sources of funds originating from abroad by these countries, whether by way of foreign debt, foreign direct investment or portfolio investment. The capital inflow from overseas to domestic is an essential requirement for developing countries to boost the economy.

Table 1. Average Ratio of Foreign Debt, Foreign Direct Investment, Investment to GDP Ratio of ASEAN-8, 1994-2018

\begin{tabular}{|c|c|c|c|}
\hline Negara & $\begin{array}{c}\text { External Debt to } \\
\text { PDB Ratio }\end{array}$ & FDI to GDP Ratio & $\begin{array}{c}\text { Portfolio Investment } \\
\text { to PDB Ratio }\end{array}$ \\
\hline Indonesia & 0.30 & 0.06 & 0.02 \\
\hline Malaysia & 0.58 & 0.03 & 0.01 \\
\hline Thailand & 0.35 & 0.02 & 0.01 \\
\hline Philippines & 0.29 & 0.02 & 0.002 \\
\hline Vietnam & 0.48 & 0.07 & 0.01 \\
\hline Myanmar & 0.20 & 0.04 & 0.000087 \\
\hline Cambodia & 0.54 & 0.13 & 0.0013 \\
\hline Laos & 1.04 & 0.08 & 0.03 \\
\hline
\end{tabular}

Source: Composed by the authors on data from the https://data.worldbank.org/. Data downloaded in January 2020 
Table 1 shows the average ratio sources of foreign funds to GDP in the ASEAN-8 countries for the 1994 to 2018 period, consisting of foreign debt, foreign direct investment and portfolio investment. The ratio of foreign debt to GDP confirms the huge use of foreign debt to GDP, which offers a red light for the country of Laos (1.04), where the use of foreign debt has exceeded 0.60 to GDP as a maximum condition for debt sustainability. Subsequently, there are yellow lights for Malaysia (0.58), Cambodia (0.54), Vietnam (0.48), Thailand $(0.35)$ and Indonesia (0.30), for the reason that the use of foreign debt has exceeded 0.30 to GDP. Meanwhile, the use of foreign debt in the Philippines (0.29) and Myanmar (0.2) remains green because it is relatively safe with ratios which are below 0.30 .

However, if we note the average ratio of foreign direct investment and portfolio investment to GDP, it reveals the average value of the ratio of foreign direct investment and portfolio investment to GDP during the research period is below 0.15 , with the highest ratio achieved by Cambodia (0.13), followed by Laos (0.08), Vietnam (0.07), Indonesia (0.06), Myanmar (0.04), Malaysia (0.03), Thailand (0.02) and the Philippines (0.02). Similarly, it can be seen that the average ratio of the portfolio investment achieved the highest average ratio at 0.03 , whereas the lowest average ratio, which was 0.000087 , was achieved by Myanmar.

The data above shows us that greater use of foreign debt for development activities in the ASEAN-8 countries only causes a larger ratio of foreign debt to GDP and may threaten the national economy. Foreign debt has created several obligations, namely the obligation to pay principal debt instalments and interest on the debt. This obligation then becomes a debt burden which becomes significant if the ability to develop countries' economies to generate foreign export exchange is relatively low. This is attributable to the low growth in exports. Consequently, the higher a country's foreign debt, the lower the ability to repay the debt.

Therefore, foreign debt is only required at a reasonable level - additional foreign debt can be set at a specific limit if it has a positive impact on economic growth, so that debt payments do not disrupt the stability of the domestic economy. The level of accumulated foreign debt to GDP that is above the tolerable limit can hinder a country's economic growth. This limitation is termed 'fiscal sustainability' and according to [1], is measured using the ratio of external debt to GDP. [2] say that fiscal sustainability is a valuable criterion for evaluating whether fiscal policy is on the appropriate long-term path. Fiscal sustainability is challenged when the debt-to-GDP ratio is overvalued and government revenue is insufficient to continue to finance the costs of issuing new government debt. [3], states that debt sustainability is still tolerable if the debt-to-GDP ratio is not more than $60 \%$.

Concerning this serious problem that developing countries will be confronted by in the form of foreign debt payment as a consequence of the addition of foreign debt, it is essential to continue to encourage the use of other sources of foreign funds in the ASEAN-8. These funds can be in the form of foreign direct investment and portfolio investment, where the ratio of foreign direct investment and portfolio investment to GDP remained low during this specific study.

Many macroeconomic variables influence foreign direct investment as demonstrated by previous studies, such as capital flight $[4,5,6,7,8]$, loan interest rates $[6,7,8,9]$, inflation $[5,10]$, exchange rates [6] and economic growth $[5,7,9]$. Those variables are a major factor and can significantly influence foreign direct investment. This paper intends to obtain empirical evidence on what macroeconomic variables have a significant effect on foreign direct investment in the ASEAN-8 countries, using panel data from the ASEAN-8 countries covering the period 1994 to 2018.

\section{Literature Review}

In explaining the determinants of an investment model, this study follows Keynes' internal fund and neo-classical theories, as well as Tobin's q ratio. To complement those theories, we refer to the previous empirical research which relates to our study. Based on the marginal efficiency of capital (MEC) concept, [11], explained investment demand. According to [11], demand for investment is determined by the size of the present value of the expected net income for additional capital expenditures at the current cost of capital. Thus, based on this theory, investment depends on the discount rate which states the flow of gains expected in the future at the present cost of additional capital. 
The greater the present value of the expected net gain on additional capital expenditures compared to the current level of costs, the greater the demand for investment. Based on this particular theory, investment demand $\left(\mathrm{FDI}_{\mathrm{t}}\right)$, depends on the rate of return (R), the real interest rate (i) and the cost of capital incurred $\left(C_{k}\right)$ or is formulated in the form of a function to be:

$\mathrm{FDI}_{\mathrm{t}}=f\left(\mathrm{R}, \mathrm{INT}, \mathrm{C}_{\mathrm{k}}\right)$

where $\mathrm{R}$ is the return, INT is the interest rate and $\mathrm{C}_{\mathrm{k}}$ is the costs incurred to obtain capital stock.

Based on internal funds theory of investment, the demand for an investment is determined and depends on the level of return [12]. The rate of profit is the level of future expected profit which is signified by the difference between real interest rate and expected future risk. However, several prior studies employed inflation rate as a proxy for risk. For foreign direct investors, not only interest and inflation but also changes in exchange rates are a factor that must be considered to be a risk. A change in exchange rates (depreciation and appreciation) affects the number of investments. Thus, according to internal funds theory, the demand for investment $\left(\mathrm{FDI}_{t}\right)$, is a function of the interest rate (INT), inflation (INF) and the exchange rate (ER). Therefore, the model is:

$\mathrm{FDI}_{\mathrm{t}}=f(\mathrm{INT}, \mathrm{INF}, \mathrm{ER})$

According to neo-classical theory, a stock of capital in a firm is determined by the output and the prices of capital relative to output price. The price of capital depends on capital goods, interest rate and the tax treatment of a firm's income. Thus, it can be written as the mathematical function:

$\mathrm{FDI}_{\mathrm{t}}=f(G R T, \mathrm{k}, \mathrm{INT}, \mathrm{Tax})$

where GRT is the change in output, $\mathrm{k}$ is capital goods, $i$ is real interest rate and Tax is income tax. This study considers Tobin's q theory as a factor that influences investment. According to this theory, investment is highly dependent on the market value of capital compared to replacement costs [13]. If the market value of capital compared to replacement costs is greater than 1 ( $\mathrm{q}>1)$, firms will increase their market value by providing more capital. Conversely, if $\mathrm{q}<1$ signifies the market value of capital less than the replacement cost. In such circumstances, firms will not increase their capital. Generally, Tobin's q theory is similar to Keynes' theory, which confirms that company investment is highly dependent on the level of profit and costs. However, in Tobin's q theory, level of profit is the current market value, although in Keynes' theory, the profit level is the present value of future profits. Likewise in terms of costs, in Tobin's q theory, the cost is the replacement cost, while in Keynes' theory, the cost is the additional cost of capital goods. According to Tobin's q theory, the desired investment or stock of capital $\left(\mathrm{I}_{\mathrm{t}}\right)$ is influenced by the market price $(\mathrm{Pm})$ and the cost of replacing capital goods $\left(\mathrm{C}_{\mathrm{R}}\right)$.

$\mathrm{FDI}_{\mathrm{t}}=f\left(\mathrm{Pm}, \mathrm{C}_{\mathrm{R}}\right)$

where $\mathrm{Pm}$ is the market price of capital stock and $\mathrm{C}_{\mathrm{R}}$ is the replacement cost of capital stock. By combining equations (1) to (4), we have:

$\mathrm{FDI}_{\mathrm{t}}=f\left(\mathrm{R}, \mathrm{INT}, \mathrm{C}_{\mathrm{k}}, \mathrm{INF}, \mathrm{ER}, G R T, \mathrm{k}\right.$, Tax, Pm, $C_{R}$ )

where $\mathrm{R}$ is the expected rate of return, INT is the interest rate, $\mathrm{CK}$ and $\mathrm{CR}$ are the costs incurred to obtain capital stock, INF is inflation, ER is the exchange rate, GRT is the change in output, $\mathrm{k}$ is availability of capital goods, Tax is income tax and $\mathrm{Pm}$ is the market price of capital stock. However, due to the availability and limitations with respect to data for each country, this paper uses the interest rate, inflation, exchange rate and economic growth as the estimator variables in determining foreign direct investment. Based on that, the formulation of the equation is:

$\mathrm{FDI}_{\mathrm{t}}=f(\mathrm{INT}, \mathrm{INF}, \mathrm{ER}, G R T)$

Besides the variables in equation (6), another independent factor that cannot be ignored to examine its correlation with foreign direct investment is the capital flight variable. In this study, we use capital flight proposed by the World Bank [14], which estimates the capital flight by measuring the difference between the residual of source of funds and use of funds. Sources of funds include all net official inflows (increases in public sector net external debt and net foreign direct 
investment flows). However, the use of funds includes current account deficits and changes in foreign exchange reserves. Outward capital flight occurs when the source of funds is higher than the use of funds and vice versa. The equation for this approach can be written as:

$\mathrm{CF}=(\Delta \mathrm{ED}+\Delta \mathrm{FDI})-(\mathrm{CA}+\Delta \mathrm{OR})$

where $\mathrm{CF}$ is capital flight, DED is change in external debt, $\triangle \mathrm{FDI}$ is net private direct investment, $\mathrm{CA}$ is current account (surplus/deficit) and $\Delta \mathrm{OR}$ is change in foreign exchange reserve. The use of the residual approach to measuring capital flight in the ASEAN-8 countries refers to the empirical study conducted by $[15,16,17,18,19]$ as well as $[20]$. We add the capital flight variable into formula (6), then the research model is obtained:

$\mathrm{FDI}_{\mathrm{t}}=f(\mathrm{CF}, \mathrm{INT}, \mathrm{INF}, \mathrm{ER}, G R T)$

Prior empirical studies regarding the positive impact of capital flight on foreign direct investment, such as $[4,6]$, who state that capital flight has a positive effect on foreign direct investment. Meanwhile, the opposite results are shown by [5,7], as well as [8], who state that capital flight has a negative impact on foreign direct investment.

A further macroeconomic variable that determines foreign direct investment is interest rate. A decrease in loan interest rate has an effect on lowering credit interest but then encourages greater investment. Demand for capital depends on the loan interest rate which measures the cost of the funds to finance foreign direct investment [21]. To establish foreign direct investment that is profitable, the outcome (revenue from an increase in the future production of goods and services) must be higher than its costs (payments for loanable funds). However, if the loan interest rate increases, it creates lower profitable foreign direct investment; thus, demand for investment goods decreases. The investment function relates to the amount of investment and the interest rate for the reason that the interest rate is the cost of funds [12]. Investors have willing to pay off the loan interest rate for investment if they expect to obtain a greater income from their investment than it costs to fund. This profit is the main reason that investors are attracted to boosting foreign direct investment. One possible reason to make investment profitable is a low interest rate. Previous studies confirm the negative effect of interest on investment, such as $[6,7,8,9]$, which assert that interest rate has a negative effect on foreign direct investment.

Empirically, inflation and exchange rate have a negative effect on foreign direct investment. The effect of inflation on foreign direct investment has been shown in the work of $[5,10]$. They show empirical evidence of the negative and significant influence of inflation on foreign direct investment. Conversely, the result obtained by [6], establishes the negative effect of the exchange rate on foreign direct investment. This finding confirms that higher inflation and depreciation of the exchange rate results in a drop in foreign direct investment.

Theoretically, there is a relationship between national output and foreign direct investment. Economic growth reflects the market size of a country, which demonstrates higher potential economic and aggregate demand. Thus, it is a good signal for foreign investors to invest in a domestic country and as a result, increases foreign direct investment. Conversely, a decrease in economic growth creates a decline in foreign direct investment. This is in line with the empirical study conducted by $[5,9]$, who conclude that economic growth has a positive and significant effect on foreign direct investment. However, in the research undertaken by [7], the effect of economic growth on foreign direct investment illustrates the opposite.

\section{Data and Methodology}

\subsection{Data}

This study uses panel data for the ASEAN-8 countries with annual data from 1994 to 2018. All research data uses secondary data obtained online from official World Bank publications.

Foreign direct investment is the total value of the realisation of foreign direct investment (FDI) in a million USD in the ASEAN-8 countries. The value of capital flight is calculated using the residual approach used by the World Bank [14], which is the amount of residual value that indicates the net difference from funding sources in relation to the use of funds. Sources of funds include all net official inflows (increase in net public sector external debt) and net foreign direct investment flows. Fund users include current account deficits 
and additional reserves. Outward capital flight occurs when the source of funds exceeds the use of funds and vice versa for the flight of capital in (Inward Capital Flight). Interest rate (INT) is the reference interest rate for international loans which will be proxied using SIBOR (Singapore Inter-Bank Offered Rate). The use of SIBOR reference lending rates is related to the majority of foreign direct investors in the ASEAN-8 from Singapore, whose investment funding uses bank funds.

Inflation is the increase in price in the ASEAN-8 countries, calculated based on the CPI. The exchange rate is the amount of the nominal exchange rate in the ASEAN-8 countries against the US dollar. Economic growth is the increase in economic growth value in the current year in the ASEAN-8 countries, which is measured based on constant prices in 2010.

\subsection{Econometrics Methodology}

The econometric methodology used in our model in equation (8), is a multiple regression equation model using panel data, which is a combination of time series and cross-section data. To obtain the best panel model, the common effect model, fixed-effect model and random effect model will be tested, by way of the Chow and Hausman tests. In our research model equation, we will also test classical assumptions and undertake other essential tests.

To examine the effect of macroeconomic variables on FDI, we use a panel data with fixed effect estimation. Additionally, classical assumption and other essential tests will be conducted on the model. Consider the following standard panel regression:

$Y_{i t}=\beta_{0}+\beta_{1} X_{i t}+u_{i t}$

where $\mathrm{i}$ is country cross-section, $\mathrm{t}$ represents time. $Y$ is dependent variable, and $X$ is matrix of explanatory variables. $u$ is error disturbance, with:

$u_{i t}=\mu_{i t}+v_{i t}$

where $\mu_{i}$ denotes the unobservable country-specific effect and $v_{i t}$ represents the remainder disturbance. The model does not account for country-specific effects such as cultural, political, and institutional elements that change over time [22]. [23] demonstrates that these unobservable countryspecific effects can be accounted for in a one-way error component model. The following is the equation for the fixed effect:

$Y_{i t}=\beta_{0}+\beta_{1} X_{i t}+\mu_{i t}+v_{i t}$

For each country observation $i$, averaging equation

$\bar{Y}_{i}=\beta_{0}+\beta_{1} \bar{X}_{i}+\mu_{i}+\bar{v}_{i}$

Then subtracting Equation (12) from Equation (11) gives:

$$
Y_{i t}-\bar{Y}_{i}=\beta\left(X_{i t}-\bar{X}_{i}\right)+\left(v_{i t}-\bar{v}_{i}\right)
$$

Note that the unobservable country-specific effect, $\mu_{i}$, has disappeared. The transformation process in Equation (13) is known by within transformation.

In this study, we use various macroeconomics variables that have a significant effect of foreign direct investment as formula (8), both theoretically and empirically. The most relevant empirical studies include $[4,5,6,7,8,9]$.

[4] investigates the correlation between capital outflow and direct investment in Russia and China. The estimation results conclude that capital flight has a positive correlation and significant impact on direct investment in Russia, whereas in China it shows the opposite. [5], uses the ratio variable for capital flight to GDP, economic growth, domestic investment the previous year, inflation and private credit to examine their effects on direct investment in 15 countries in the former French colonies in Africa from 1970 to 2005 . The results indicate that except for the economic growth variable, all independent variables have a significant effect on the direct investment variables. Subsequently, the variable of capital flight ratio to GDP and inflation has a negative influence on the direct investment variable. Meanwhile, the economic growth variable is direct investment from the previous year and private credit that has a positive influence on the direct investment variable.

[6], applies the variables for capital flight, interest rates and exchange rates to study their effects on investment in Nigeria from 1970 - 2006. The results showed that there is a positive but not significant effect of the capital flight variable on investment, while interest rates and exchange rates have a negative effect on investment. In their study, [7], 
estimate the effect of capital flight, government spending, interest rates, economic growth the previous year, exchange rate and terms of trade on investment in the Caribbean country of Trinidad and Tobago, for the period 1971-2008. The results revealed that the capital flight variables and economic growth in the previous year has a negative and significant effect on investment, although government spending and the economic growth variable has a positive and significant influence on investment. [9], applies investment variables from previous years, capital flight, economic growth, private credit, real interest rate, terms of trade and foreign investment debt in 21 countries in Asia, Africa and Latin America covering the period 1975 - 2000. The research results demonstrated the following: (1) except for the interest rate variable and foreign debt, all other independent variables have a significant effect on investment, (2) capital flight, real interest rates and terms of trade have a negative influence on investment and (3) the previous year's investment variable, economic growth, private credit and foreign debt has a positive influence on investment.

Furthermore, regarding the research conducted by [8], on the impact of capital flight, interest rates, investment credit, terms of trade and foreign debt in relation to private sector investment in Kenya for the period 1970 to 2012, the results showed that (1) except for the terms of trade and foreign debt variables, all variables have a significant effect in connection with private investment, (2) capital flight and interest rate variables have a direct negative influence on private investment, and (3) investment credit variables, terms of trade and debt abroad has a direct negative influence on private investment.

In this study, we use various macroeconomic variables that are thought to have an influence on foreign direct investment as the empirical results above show. Hence, the research model is described as follows:

$$
\begin{aligned}
& F D I_{i t}=\theta_{i}+\beta_{1} C F_{i t}+\beta_{2} I N T_{i t}+ \\
& \beta_{3} I N F_{i t}+\beta_{4} E R_{i t}+\beta_{5} G R T_{i t}+\varepsilon_{i t}
\end{aligned}
$$

In equation (14), $\mathrm{i}=1,2, \ldots, \mathrm{N}$ for countries crosssection, $\mathrm{t}=1,2, \ldots, \mathrm{T}$ for time series, FDI represents the realisation of foreign direct investment, CF describes capital flight, INT shows the loan interest rate, INF is the inflation rate, ER is the exchange rate, GRT is economic growth, meanwhile $\theta_{i}$ is the country specification effect.

\section{Empirical Results}

\subsection{Descriptive Statistics}

Table 2 shows the various research data from the variables that will be used in this research during the twenty-five-year study period. With respect to capital flight data, it can be seen that the minimum value is $-50,188.08$ and the highest is $80,315.46$. This shows that there was capital flight out of USD $80,315.46$ million and capital flight of USD $50,188.08$ million that occurred in Indonesia in 2018 as a result of the increasing growth in debt from the public sector. However, capital inflows occurred in Thailand in 2016 amounting to USD 50,188.08 million. Furthermore, the data on loan interest rates using the SIBOR reference rate indicates a minimum value of $0.58 \%$ occurred during the 2014 2018 period, whilst a maximum value of $6.87 \%$ took place in 2000. This situation confirms that the loan interest rate is at a low value for the last year and is profitable for investors whose funding comes from international banks in the ASEAN.

Table 2. Descriptive Statistics

\begin{tabular}{|c|c|c|c|c|c|}
\hline Variable & \multirow{2}{*}{ Abbreviation } & Mean & Std Dev. & Min. & Max. \\
\hline Capital Flight & CF & 3184.994 & 18042.82 & -50188.08 & 80315.46 \\
\hline Loan Interest Rate & INT & 2.73 & 1.97 & 0.58 & 6.87 \\
\hline Inflation & INF & 8.14 & 13.49 & -1.71 & 125.27 \\
\hline Exchange Rate & ER & 4661.28 & 6058.14 & 2.50 & 22602.05 \\
\hline Economic Growth & GRT & 6.14 & 3.27 & -13.13 & 13.84 \\
\hline Foreign Direct Investment & FDI & 4149.925 & 5181.558 & -4550.360 & 25120.73 \\
\hline
\end{tabular}


A further fact relates to the inflation variable, where, in general, the average inflation rate in all ASEAN-8 countries is also relatively large at $8.14 \%$. The interesting point pertaining to this inflation data is that there is a maximum inflation value of $125.27 \%$, which occurred in Laos in 1999. This relates to Laos, which has only been a member of the ASEAN for two years and where initially, joining as a member of ASEAN was limited to the distribution of goods and logistics, and where some of the population's basic needs were met by the surrounding countries. However, at present, with the development of the country's economy, their basic needs have been met by logistics distribution in the country and by the ASEAN countries.

Furthermore, the domestic currency exchange rate against the US dollar demonstrates the purchasing power of the ASEAN-8 currencies against one US dollar, where the strongest purchasing power, 2.50 Malaysian Ringgit against 1 US dollar occurred in 1995. Meanwhile, regarding the purchasing power of currency, the weakest amount was 22602.25 Vietnamese Dong against 1 US dollar in 2018. Regarding economic growth data, it can be seen that even though the average economic growth achieved in the ASEAN-8 countries is relatively high at $6.14 \%$, there are countries that are able to achieve economic growth that is relatively high, a maximum of $13.84 \%$ (Myanmar in 2003) and a country with minimum economic growth of -13.13, namely Indonesia in 1998, when the financial and monetary crisis occurred. Nevertheless, data on foreign debt growth shows that the average growth in the ASEAN-8 is $6.96 \%$. The highest growth in relation to foreign debt occurred in Thailand in 1995, while the lowest growth in debt was in Vietnam in 2000.

\subsection{Result of the Chow and Hausman Tests}

Table 3 reveals the results of the Chow and Hausman tests for equation (4). The Chow test reveals the probability of Cross-section Chi-Square $<$ alpha $(5 \%)$ or $0.0000<0.05$, whereas the Hausman test demonstrates the probability of Crosssection Random < alpha $(5 \%)$ or $0.0011<0.05$. Based on those tests, it can be concluded that the most appropriate panel data regression estimation for this study is a fixed effects model (FEM).

Table 3. Results of Chow and Hausman Tests

\begin{tabular}{|c|l|c|c|}
\hline Num. & \multicolumn{1}{|c|}{ Testing } & Value & \multicolumn{2}{|c|}{ Conclusion } \\
\hline \multirow{2}{*}{1.} & Chow test & 47.192 & \multirow{2}{*}{ fixed effect model (FEM) } \\
\cline { 2 - 3 } & Cross-section Chi-square & 0,0000 & \\
\cline { 2 - 3 } & Prob. & \multicolumn{2}{|c|}{} \\
\hline \multirow{2}{*}{2.} & Hausman test & 22.2212 & \multirow{2}{*}{ fixed effect model (FEM) } \\
\cline { 2 - 3 } & Cross-section random & 0.0011 & \\
\cline { 2 - 3 } & Prob. & \multicolumn{2}{|c}{} \\
\hline
\end{tabular}

\subsection{Result of Classical Assumption and Normality Tests}

It is necessary to test the classical assumptions (multicollinearity, heteroscedasticity and autocorrelation) and the normality tests to determine the validity of the research data. Table 4 presents the correlation matrix to detect the presence of multicollinearity problems. According to [24]
Asteriou and Hall (2015), the multicollinearity problem exists if there is a correlation between the independent variables higher than 0.80 . Table 4 shows the correlation between independent variables with less than 0.80 . Thus, it can be concluded that there is no multicollinearity problem in relation to our model.

Table 4. The Result of Multicollinearity Test

\begin{tabular}{|c|c|c|c|c|c|}
\hline & DINT & INF & LNER & GRT & GDEBT \\
\hline CF & 1.0000 & -0.2424 & 0.0035 & 0.2468 & -0.0081 \\
\hline INT & -0.2424 & 1.0000 & 0.2711 & -0.0831 & 0.0814 \\
\hline INF & 0.0035 & 0.2711 & 1.0000 & 0.0451 & 0.0029 \\
\hline ER & 0.2468 & -0.0831 & 0.0451 & 1.0000 & 0.0261 \\
\hline GRT & -0.0081 & 0.0814 & 0.0029 & 0.0261 & 1.0000 \\
\hline
\end{tabular}


Table 5. The Results of the Heteroscedasticity, Autocorrelation and Normality Tests

\begin{tabular}{|c|c|c|c|}
\hline Num. & $\begin{array}{r}\text { Testing } \\
\end{array}$ & Value & Conclusion \\
\hline \multirow[t]{5}{*}{1.} & Heteroscedasticity (White test) & & \\
\hline & n-observed & 200 & \multirow{4}{*}{$\begin{array}{c}X_{\text {count }}^{2}<X_{26 ; 0.05}^{2} \\
\text { no heteroscedasticity }\end{array}$} \\
\hline & $r$-squared & 0.1063 & \\
\hline & Chi Square count & 21.2720 & \\
\hline & Chi Square table $(20 ; 0.05)$ & 31.4104 & \\
\hline \multirow[t]{6}{*}{2.} & Autocorrelation (Durbin-Watson test) & & \\
\hline & Durbin-Watson count & 1.9464 & \multirow{5}{*}{$\begin{array}{c}\mathrm{D}_{\mathrm{U}}<1.9464<4-\mathrm{D}_{\mathrm{U}} \\
\text { no autocorrelation }\end{array}$} \\
\hline & Nilai $D_{L}$ & 1.7180 & \\
\hline & Nilai $\mathrm{D}_{\mathrm{U}}$ & 1.8200 & \\
\hline & Nilai 4-D $\mathrm{D}_{U}$ & 2.1800 & \\
\hline & Nilai 4- $\mathrm{D}_{\mathrm{L}}$ & 2.2282 & \\
\hline \multirow[t]{3}{*}{3.} & Normality (Jarque-Berra test) & & \\
\hline & Jarque-Berra & 4.7472 & \multirow{2}{*}{ normally distributed } \\
\hline & Prob. & 0.0931 & \\
\hline
\end{tabular}

Table 5 presents the results of the White test to detect the presence of heteroscedasticity problems. The results of the Durbin-Watson test to detect the presence of autocorrelation problems and the Jarque Berra test to see whether or not the residuals of the data are normally distributed, conclude that data are free of heteroscedasticity and autocorrelation problems and that the residual of the data is normally distributed

\subsection{Result of Fixed Effect Model}

Table 6 reveals the result of panel data estimation with the fixed effect model. Capital flight and economic growth have a positive and significant effect on foreign direct investment at the 1 percent level. Loan interest rates, inflation and exchange rates have a negative and significant effect on foreign direct investment with different significance levels. The determination coefficient (r-square) and the adjusted coefficient of determination (adjusted $\mathrm{r}$ square) are 0.7645 and 0.7481 , respectively. Rsquared shows the independent variables to explain the variation in the change in foreign direct investment; $76.45 \%$ or $74.81 \%$ after adjustment, while the remaining $23.55 \%$ or $25.19 \%$ after adjustment is explained by variations in other variables which are not included in our model in this particular study. The F-statistic for our model is 46.46. It is significant at the 1 percent level. This result implies that all independent variables have a significant effect on the dependent variable at the 1 percent level.

Table 6. Fixed Effect Estimation

\begin{tabular}{|l|c|c|c|}
\hline \multicolumn{1}{|c|}{ Variable } & Estimate & t-Statistics & Prob. \\
\hline CF & 0.123989 & 11.9160 & $0.0000^{* * *}$ \\
\hline INT & -394.0158 & -4.3411 & $0.0000^{* * *}$ \\
\hline INF & -7.609819 & -2.0881 & $0.0381^{* *}$ \\
\hline ER & -110.9557 & -2.5602 & $0.0113^{* *}$ \\
\hline GRT & 384.8721 & 6.2560 & $0.0000^{* * *}$ \\
\hline Constant & 6695.265 & 11.4512 & $0.0000^{* * *}$ \\
\hline $\mathrm{R}^{2}$ & 0.7645 & & \\
\hline Adj. $\mathrm{R}^{2}$ & 0.7481 & & \\
\hline F-statistic & & 46.4663 & $0.0000^{* * *}$ \\
\hline Durbin-Watson stat & 2.0357 & & \\
\hline
\end{tabular}

Notes:

1. The dependent variable is capital flight.

2. The symbols $*, * *, * * *$ denote statistical significance at the $10 \%, 5 \%$ and $1 \%$. 


\section{Discussion}

The estimation results of the effect of capital flight, interest rates, inflation, exchange rates and economic growth on foreign direct investment are consistent with the theory. The magnitude of the $\mathrm{R}^{2}$ is 0.7645 . This result indicates that the variation in the change in the dependent variable (FDI) can be explained by the variation in the change in the independent variable of approximately $76.45 \%$. Thus, the ability of the independent variable in explaining the dependent variable is $76.45 \%$, whereas the remaining $24.55 \%$ is explained by other variables that are not included in the model.

First, we will consider the effect of capital flight on foreign direct investment. We find that capital flight has a positive and significant effect on foreign direct investment with a coefficient of 0.1239 . This result implies that an increase in the residual value (outward capital flight) of capital flight indicates an additional source of outside funds of 1 million USD that encourages an increase in foreign direct investment in the ASEAN-8 by 0,1239 million USD. This result is in agreement with the empirical studies performed by $[4,6]$, who show empirical evidence of the positive and significant effect of capital flight on foreign direct investment. However, our result contrasts with the research of $[5,7,8]$, who find the opposite as regards the effect of capital flight on foreign direct investment.

The implication of this finding is that an increase in capital outflow (outward capital flight) has a positive and significant effect on influencing foreign direct investment in the ASEAN-8 countries. The positive direction of capital flight to foreign direct investment refer to the explanation given in the study conducted by [4]. First, for developing countries which have a limitation in funding sources, the role of capital inflow in the form of foreign debt and foreign direct investment are the main source of finance for the development of countries, seeing that the sources of internal finance in the form of taxes and savings are limited. The results of this study have reaffirmed the fact that the greater the residual value of capital flight, the greater the foreign direct investment entering the ASEAN-8 countries. Second, the greater the residual of capital flight indicates the greater confidence of foreign investors to invest in the domestic economy, thus encouraging higher foreign direct investment. Third, the high confidence level of foreign investors in relation to the repayment of foreign debt and interest by the government or private sector besides the transfer of profits abroad from direct foreign investment activities by foreign investors without any restrictions or obstacles from the policymakers' regulations. This implies that the large residual of capital flight positively indicates a higher amount of foreign direct investment.

Furthermore, the results of this study establish that loan interest rates have a negative effect on foreign direct investment. The loan interest rate is the main factor determining the rate of foreign direct investment. In this study, we refer to the SIBOR as a loan interest rate given that SIBOR is connected to the nature of foreign direct investment which comes from the international banks. The reference for interest rate (SIBOR, LIBOR), is generally used as a reference in determining loan interest rates for international funding since it is the basic function of investment which relates the amount of investment to a certain investment interest rate because the interest rate is the cost of borrowing funds [12] (Mankiw, 2012). The negative coefficient of loan interest rate on foreign direct investment is consistent with the results of previous empirical studies, such as $[6,7,8,9]$, who state that the loan interest rate has a negative effect on foreign direct investment. Concerning foreign investors whose funding is derived from financial institutions, foreign direct investment activities depend on the rate of loan interest rate as it is a component of the cost of funds used to finance foreign direct investment. Foreign investors are basically willing to pay loan interest for foreign direct investment activities when the funds can be used for activities which are expected to generate greater income than the amount invested. This excess revenue over expenditure (profit) is a source for investors to pay interest on a loan, where this condition occurs when the cost of funds (interest) in the market is relatively cheap.

The next variable is inflation. Our result shows that inflation rate has a negative and significant effect on foreign direct investment. The result of this study is in agreement with the empirical results obtained by [5], who asserts that the inflation variable has a negative effect on foreign direct investment. This empirical finding confirms that higher inflation results in a decline in foreign direct investment in the ASEAN-8 countries. Thus, inflation is a factor that should be considered by investors who wish to 
invest funds in the ASEAN-8 countries. According to [25], the reasons for the negative effect of inflation on investment are first that inflation causes higher bank interest rates, both savings and credit interest rate. A higher interest rate increases the cost of funds; thus, funds are more expensive. Hence, it affects the real sector and reduce investors' interest in utilising funds from the banking sector due to the high cost of capital, particularly for those whose funding sector depends on bank loans. Second, inflation reduces the value of national savings and the investor tends to choose to invest their funds in good assets. Third, inflation results in a decline in the real value of public wealth in the form of cash. In other words, the value of money becomes smaller because the commodity price per unit increases nominally. In contrast, concerning those who have considerable wealth in the form of fixed assets or non-liquid assets; those assets actually benefit from the increase in prices. Thus, inflation leads to a greater income gap. Fourth, inflation hampers economic growth. Specifically, a production slump occurs, both for export-orientated products and products for the domestic market. Fifth, in terms of foreign exchange rate, the domestic currency depreciates against foreign currencies which in turn causes other problems, for instance an increase in government obligations to foreign creditors.

The following result pertaining to this study is the negative effect of exchange rate on foreign direct investment. This result implies that an increase in the exchange rate of the domestic currency (depreciation) against the US dollar causes a decrease in foreign direct investment. Conversely, a decrease in the domestic currency exchange rate (appreciation) generates an increase in foreign direct investment. Several previous empirical studies which conclude that the exchange rate has a negative effect on foreign direct investment include [6,7]. According to [26], the occurrence of depreciation or devaluation tends to affect the trade exchange rate (terms of trade). A depreciation of the exchange rate stimulates export production because export prices fall in foreign currency so that the export volume increases. This occurs if the raw materials and supporting materials for export products produced domestically. Meanwhile, if the raw materials and supporting materials come from abroad, the depreciation in the domestic exchange rate causes a decrease in foreign direct investment, because depreciation tends to push import prices up.
The last finding as regards this study is the positive and significant effect of economic growth on foreign direct investment. This result indicates that an increase in economic growth produces an increase in foreign direct investment. This finding is in line with economic theory where economic growth is considered positively by foreign investors prior to making foreign direct investments in the ASEAN-8 countries. The result of this study supports the empirical studies performed by [5,9], which conclude that economic growth has a positive and significant effect on foreign direct investment.

\section{Conclusion and Recommendations}

This study reveals empirical evidence that capital flight and economic growth have a positive and significant effect on foreign direct investment. This implies that an increase in capital flight and economic growth has also encouraged foreign direct investment to increase. Meanwhile, loan interest rates, inflation and exchange rates have a negative and significant effect on foreign direct investment. These results signify that an increase in the SIBOR loan interest rate, the increase in the inflation rate and the depreciation of the domestic currency trigger a decline in foreign direct investment. These results have been consistent and support the results of previous studies.

Our findings produce several recommendations. First, it is necessary to optimise the residual value of capital flight in the form of capital retained for productive and valuable things, such as for job creation, in order to reduce unemployment, poverty and increase people's purchasing power. Second, this study encourages the Central Bank to reduce the interest rate, which is followed by a reduction in the banking sector, as well as encouraging the banking system to play a role as an intermediary so that savings increase. Hence, this will create a wider financing scheme with lower costs and moreover, makes it inexpensive to support foreign direct investment activities in the ASEAN-8 countries. Third, we encourage maintaining inflation at the targeted rate via a mix of monetary policy, fiscal policy and real policy. Fourth, maintaining and encouraging the domestic exchange rate to be stable, whilst efforts to strengthen the exchange rate in the longterm must be continued. Fifth, strengthening the prospects of the national economy is always positive with the aim of encouraging the creation of national economic growth that provides various profit opportunities for business activities and attracts domestic and foreign investors.

Our work can be extended for a future empirical study such as adding another region and compare the result with this study. 
References:

[1] Auerbach, A. J., \& Gorodnichenko, Y. (2017). Fiscal stimulus and fiscal sustainability (No. w23789). National Bureau of Economic Research.

[2] Afonso, A., \& Jalles, J. T. (2014). A longer-run perspective on fiscal sustainability. Empirica, 41(4), $821-847$

[3] Edwards, S. (2003). Debt relief and fiscal sustainability. Review of World Economics, 139(1), 38-65.

[4] Sicular, T. (1998). Capital Flight and Foreign Investment: Two Tales From China and Russia. World Economy, 21(5), 589-602.

[5] Ndiaye, A. S. (2007). Impact of capital flight on domestic investment in the Franc Zone. In African Development Bank and United Nations Economic Commission for Africa, eds., Africa's Development Challenges and Opportunities in the Global ArenaProceedings of the African Economic Conference (pp. 317-355).

[6] Adesoye, A. B., Maku, O. E., \& Atanda, A. A. (2012). Capital Flight and Investment Dynamics in Nigeria: A Time Series Analysis (1970-2006) (No. 35836). University Library of Munich, Germany.

[7] Salandy, M., \& Henry, L. (2013). The impact of capital flight on investment and growth in Trinidad and Tobago, 1971-2008. Retrieved from https://pdfs.semanticscholar.org

[8] Gachoki, C., \& Nyang'oro, O. (2016). Impact of Capital Flight on Private Investment in Kenya. International Journal of Economics, 1(2), 115.

[9] Yalta, A. Y. (2010). Effect of capital flight on investment: Evidence from emerging markets. Emerging Markets Finance and Trade, 46(6), 4054.

[10] Rahmon, A. B. (2017). An empirical investigation of capital flight and domestic investment in Nigeria (1980-2015). Journal of Economics and Sustainable Development, 8(24), 8-16.

[11] Keynes, J. M. (2018). The general theory of employment, interest, and money. Springer.

[12] Mankiw, N. G. (2012). Macroeconomics $\left(5^{\text {th }}\right.$ edition). New York: Worth Publishers

[13] Romer, D. (2012). Advanced macroeconomics. McGraw Hill.

[14] Erbe, S. (1985). The flight of capital from developing countries. Intereconomics, 20(6), 268275. ttp://dx.doi.org/10.1007/BF02925467

[15] Dooley, M. P. (1986). Country-specific risk premiums, capital flight and net investment income payments in selected developing countries. International Monetary Fund Departmental Memorandum, 17.

[16] Collier, P., Hoeffler, A., \& Pattillo, C. (2004). Aid and capital flight. IMF: Research Department.

[17] Vespignani, J. L. (2008). Capital flight, saving rate and the golden rule level of capital: Policy recommendations for Latin American countries. American Review of Political Economy, 6(2), 1-15.

[18] Okoli, M. N., \& Akujuobi. (2009). Determinants of capital flight: The case of Nigeria. International Journal of Development and Management Review, 4(1), 233-246.

[19] Ozer, A., Doker, A. C., \& Turkmen, A. (2013). Analysis of capital flight in developing countries: A study on Turkey between 1980 and 2010. In: International Conference on Eurasian Economies.

[20] Istikomah, N., Suhendra, I., Anwar, C.J. (2020). On Capital Flight from the ASEAN-8 Countries: A Panel Data Estimation. The Journal of Asian Finance, Economics and Business (JAFEB), 7(12).

[21] Kayani, F. N. (2021). China's Mushrooming Free Trade Agreements: New Zealand and China's Upgraded Free Trade Agreement. WSEAS Transactions on Business and Economics, 18, 884893.

[22] Kotina, H., Stepura, M., Fedosov, V., Hrysohlazov, D., \& Bilinets, M. (2020). Competitiveness of Higher Education in Ukraine and Certain European Countries: Empirical Studies on Funding and Academic Attractiveness. WSEAS Transactions on Business and Economics, 17, 849-858.

[23] Baltagi, B. H. (2008). Econometric analysis of panel data (Vol. 4). Chichester: John wiley \& sons.

[24] Asteriou, D., \& Hall, S. G. (2015). Applied econometrics. Macmillan International Higher Education.

[25] Jongwanich, J., \& Kohpaiboon, A. (2008). Private investment: Trends and determinants in Thailand. World Development, 36(10), 1709-1724.

[26] Krugman, P. R., \& Obstfeld, M. (2009). International economics: Theory and policy. Pearson Education.

\section{Creative Commons Attribution License 4.0 (Attribution 4.0 International, CC BY 4.0)} This article is published under the terms of the Creative Commons Attribution License 4.0 https://creativecommons.org/licenses/by/4.0/deed.en US 